\title{
Editorial
}

\section{History: science or art?}

\author{
HENK WESSELING*
}

Is history a science or an art? There are several ways of looking at this well known and frequently debated question. One way would be to look at the categorization of disciplines as made by the Academia Europaea. This organization has given a great deal of thought to the matter, resulting for the moment in the rather practical solution of essentially distinguishing four broad categories: Humanities, Social Sciences, Natural Sciences and Life Sciences. It is noticeable that, apart from the Humanities, all other scholars use the term 'science' to describe their work. But not all of them will be considered as scientists proper because, in the English language, the word science (or sciences) in its simple form, without any adjective, refers exclusively to the natural sciences.

To a certain extent the same is true in France. Of course, the concept of the sciences humaines or the sciences de l'homme is well established - although they are not altogether too clearly distinguished from the sciences sociales - but here again 'les sciences' in its simple form is the term used for the natural sciences. Thus, the Institut de France includes five academies but only one of them simply calls itself Académie des Sciences, and that, of course, is the one for the natural sciences.

In German - and Dutch - the situation is different. The term Wissenschaft does not exclusively refer to the natural sciences. There is no Wissenschaft as such. There is Naturwissenschaft and there is Geisteswissenschaft or Kulturwissenschaft. They are different, but both are Wissenschaft. This may be because the term Wissenschaft comes from Wissen (knowledge) and although the humanities may not be scientific, obviously it cannot be denied that they are based on knowledge.

The German notion of the Kultur or Geisteswissenschaft has much to do with the development of history as a scientific discipline in the course of the 19th century. This was a new development, because originally, in its traditional or classical form, history was considered as a form of literature. After all, apart from, somewhat surprisingly, astronomy, it is the only discipline to have its own muse: Clio. Classical historians were, and still are, considered as part of classical literature: Herodotus, Livy, Tacitus and even Caesar are - or should we say were? - read at school, just as were Euripides, Virgil and Horace. This was also the case with historians like Machiavelli, Schiller and Voltaire, who were, at the same time, famous writers. This tradition continued well into the 19th century: Macaulay, Carlyle, Michelet were all typically literary historians.

* The Netherlands Institute for Advanced Study, Merjboomlaan 1, 2242 PR Wassenaar, The Netherlands. 
Then there came a reaction to this situation with the plea for the introduction of scientific methods in history. The first stage in this process of 'scientification' brought the introduction of the so-called philological and text-critical method. The principal task of the historian was supposed to be the truthful reconstruction and interpretation of historical texts and documents. The aim of a historian's work was verstehen: to understand the past. The word verstehen already indicates that this was a typically German movement, which indeed it was. But the German example was followed all over Europe. We owe a great deal to the German historical school of the 19th century. We owe it some important notions that are still part and parcel of historical thinking: the notion of development over time; that is, the diachronic concept of history, as well as the synchronic concept of history, i.e. the notion that every period has its own character and that there is a unity that connects all the phenomena during a certain period. Furthermore, we owe to it the notion that goes with this, namely that every period should be judged according to the standards of its own time or, in the famous words of the German historian Ranke, that every period is unmittelbar $z u$ Gott. All this can be summarized as what the Germans call Historismus (historicism).

Historicism strongly underlined the uniqueness of historical events. This led to the great debate at the end of the 19th century that was, in particular, animated by the German neo-Kantian philosophers Rickert and Windelband, who claimed that there were, in fact, two models of science, the model of the natural sciences which they labelled 'nomothetic' because it is interested in regularities and thus in laws, and another totally different concept of science, which they labelled 'idiographic', because it is not interested in laws but in the particular and the unique. Its aim is to give an accurate description rather than to discover laws and rules.

This was the first strategy used by historians in order to have their discipline accepted as a science: to promote their activities as a science sui generis, in its own right. It was not wholly unsuccessful but ultimately it was vulnerable because it was in contradiction to the very powerful notion of the unity of science. After all it is not easy to accept that there exist two practices that are very different but have the same name of science. But it was not only 'idiographic' theory that was criticized, for historical practice was also attacked. The criticism was that this approach to history was too narrow, too focused on great men and political events. History should also study the anonymous people who had always represented the vast majority of the population. Thus, social history came about and methods were developed to study the unknown people of the past, first in Europe, the peasants and the labouring classes, later on also in the rest of the world, the so-called 'people without history'. This led to the second strategy of historians in trying to become accepted as a science, the one of the conversion to the social sciences.

This school of thinking with which the name of the French Annales group is intimately connected, was dominant during the greatest part of the 20th century. It had a strong impact on history not only in France but also elsewhere. It played an important role in the renewal of historical studies, by introducing new themes, new approaches, new methods and new techniques. It continues to be important but, in recent years, a new school has become fashionable which may be labelled the narrative school. Essential for this school's way of thinking is the claim that history is not only not a social science but that it is not a science at all and that the purpose of doing history lies in something else, namely in the enjoyment of 'the pleasures of the past'. The background of this development is manifold. It concerns 
postmodernism and the so called 'linguistic turn', but of course it is also connected with the general decline in appreciation of the social sciences. To be a social scientist may have seemed attractive in the 1960s, but it did not sound so very sexy in the 1980s!

Who is right? The narrativists or the scientists? To the non-philosophical mind it is clear that the answer lies somewhere in the middle. If history is a science it is a rather special sort of science, but if it is to be considered as a form of literature, it is also a very special form of literature. History is different from the sciences in so far as it is very difficult to speak of scientific progress. Science in its proper sense is characterized by the accumulation of knowledge, and thus by progress. Very few school-teachers of today will have the mind of Newton or Darwin but most of them have a better insight into nature than these geniuses had. This is not the case in history. History is not based on the accumulation of knowledge. We know now more about the French Revolution than Michelet did. We can also agree that some interpretations of the Revolution have proved to be untenable, that they have been 'falsified', to put it in Popperian terms. But we cannot say that we now know the truth about the French Revolution while our ancestors did not. In this respect history is more like the arts where the idea of progress is also either absent or ambiguous. Who, for example, would say that, now that we can enjoy Appel, Albee and Andriessen, we can happily get rid of the works of Rembrandt, Shakespeare and Mozart? In this respect history may also be somewhat similar to philosophy, insofar as that discipline too is hardly considered as a story of continuous progress - from the clumsy reasonings of Plato and Aristotle to the high levels of sophistication of Heidegger's 'Nichtendes Nichts' and Sartre's 'être en soi'.

On the other hand, history is not simply literature either. This can also be pretty easily demonstrated. A novelist may write: 'It was a rainy day in Carlovia, the splendid capital of Ruritania, when Queen Diana woke up on the morning of November 11, 1945. The Queen felt miserable, she hated rain and was always depressed by it'. It is prose that may not lead straightaway to the Nobel or the Booker Prize, but, apart from aesthetic concerns, no objection can be made to it. A historian however could only write this if he or she had evidence for all his or her statements: was it indeed raining that day? Was the Queen depressed? Was this because of the weather? How does the historian know that? This the historian will have to explain by giving references and mentioning sources. In other words, like the novelist the historian writes a story, but in the historian's case sources are needed to justify the story.

Historians have often been worried by the ambiguous character of their trade. But they should not be. Whatever their discipline may be, it is appreciated both by the public at large and by their peers from other disciplines. In a way, their work is more respected than that of their colleagues in the social sciences. They can write for large audiences, while at the same time and for the same work also be praised by their fellow historians. Historians may receive the Nobel Prize for Literature but they have also received it for Economics. In short, they live in the best of two worlds and they should better enjoy it. For more than anybody else they ought to know that things may change. 